Helgoländer wiss. Meeresunters. 31, 471-484 (1978)

\title{
Fate and effects of cadmium in an experimental marine ecosystem
}

\author{
H. von Westernhagen ${ }^{1}$, V. Dethlefsen ${ }^{2}, H$. Rosenthal ${ }^{1}$, \\ G. FÜRSTENBERG ${ }^{1} \&$ J. KLINCKMANN ${ }^{1}$ \\ ${ }^{1}$ Biologische Anstalt Helgoland (Zentrale); Palmaille 9, D-2000 Hamburg 50, \\ Federal Republic of Germany, \\ and \\ 2 Institut für Kü̈ten- und Binnenfischerei, Toxikologisches Labor; Niedersachsenstraße, \\ D-2190 Cuxbaven, Federal Republic of Germany
}

\begin{abstract}
Two recirculated marine seawater systems (capacities: 150 and 300 l) were used for the study on cadmium accumulation of biological filter sludge, by the mussel Mytilus edulis and the plaice Pleuronectes platessa for a period of up to 300 days. In the contaminated system Cd concentrations varied from 2.5 to $7.0 \mu \mathrm{g} / 1$ with a mean of $4.6 \pm 1.15 \mu \mathrm{g} / 1$ (control: $1.04 \pm 0.46 \mu \mathrm{g} / \mathrm{l})$. Accumulation of $\mathrm{Cd}$ by the filter sludge from the control system as well as from the contaminated system was significant. Mean concentrations of control and contaminated sludge over the experimental period were $2.01 \pm 0.86 \mathrm{ng} \mathrm{Cd} / \mathrm{mg}$ dry $\mathrm{wt}$ and $9.98 \pm 3.55 \mathrm{ng} \mathrm{Cd} / \mathrm{mg}$ dry wt respectively. Accumulation of $\mathrm{Cd}$ by $M$. edulis both in the control and in the contaminated system was considerable. After 163 days of exposure the whole body burden of mussels rose from $0.3 \mathrm{ng} \mathrm{Cd} / \mathrm{mg}$ dry wt to around $10 \mathrm{ng} \mathrm{Cd} / \mathrm{mg} \mathrm{dry}$ w in the controls and to $70 \mathrm{ng} \mathrm{Cd} / \mathrm{mg}$ dry wt in the contaminated systems. Accumulation of $\mathrm{Cd}$ by $P$. platessa was analysed in backbone, fins, gills, liver, muscle (fillet), otolith and skin (dorsal and ventral) over a period of 280 days. Elevated $\mathrm{Cd}$ contents of livers from control specimens were noticed after 200 days and reached $1.75 \mathrm{ng} \mathrm{Cd} / \mathrm{mg} \mathrm{dry} \mathrm{wt} \mathrm{in} \mathrm{liver.} \mathrm{There} \mathrm{was} \mathrm{considerable}$ accumulation in the liver (maximum values: $3.0 \mathrm{ng} \mathrm{Cd} / \mathrm{mg}$ dry wt) and gills $(6.0 \mathrm{ng} \mathrm{Cd} / \mathrm{mg}$ $\mathrm{dry} w \mathrm{t}$ ) of specimens from the contaminated system, Cd contents of plaice exposed for identical periods of time were very variable. Growth of plaice living in the contaminated system was at times significantly slower than that of the control group. Of the three biological objects tested - filter sludge, $M$. edulis, $P$. platessa - the mussel seemed to be the most sensitive indicator of elevated Cd-concentrations, while the reaction of the plaice was slow and less distinct.
\end{abstract}

\section{INTRODUCTION}

Although cadmium is on the "black list" of water protection conventions, the total cadmium load entering estuaries and coastal waters is not likely to decrease in the near future. Reduction schemes will be implemented at the earliest in the middle of the next decade hopefully reducing emission by $50 \%$. Thus scientific concern has still to be high, since many details of accumulation and effects of this metal in marine organisms are still poorly understood. 
In recent years investigations on the effects of cadmium on aquatic organisms have begun to shift emphasis from toxicity testing by means of short-term exposures to more complex formulation of problems. Experiments employing high (ppm levels) cadmium concentrations (Eisler, 1971; v. Westernhagen et al., 1975) have been supplemented with long-term experiments at low levels (ppb) of cadmium (Greig et al., 1974; Dawson et al., 1977; Mac Innes et al., 1977; see also National Oceanic and Atmospheric Administration, 1974) and bioassays in which experimental animals were allowed to complete a full life cycle in contaminated flow-through systems (Nimmo et al., 1978).

The search for sensitive methods to investigate effects and fate of pollutants in the natural environment has prompted us to initiate experiments in small and relatively simple artificial marine ecosystems. From the results we hope to gain insight into processes occurring under natural conditions.

Although cadmium concentrations in seawater are low, ranging from 0.01 to $0.41 \mu \mathrm{g} / 1$ (Preston, 1973; Chester and Stoner, 1974) in open waters, concentrations in river estuaries are from 10 to 100 times higher. Butterworth et al. (1972) reported up to $5.8 \mu \mathrm{g} / \mathrm{l}$ in water from the Severn estuary and Eustace (1974) found cadmium concentrations of up to $3.9 \mu \mathrm{g} / 1$ in the Derwent estuary. Thus for the present study cadmium concentrations similar to those found in polluted areas $(\sim 5 \mu \mathrm{g} / 1)$ were employed.

\section{MATERIAL AND METHODS}

\section{Recirculated seawater system}

The experiments were conducted in two semi-closed recirculated seawater systems with a capacity of 150 (control) and 3001 each. The water was treated in a 601 (control), 1201 (cadmium) biological cockle-shell gritt-gravel filter, then pumped into a header tank from which it flew by gravity into the fish basins. Water flow through the filters was $21 \mathrm{l} / \mathrm{min}$ (control) and $34 \mathrm{l} / \mathrm{min}$ (cadmium). Water flow in the fish basins was $1.2 \mathrm{l} / \mathrm{min}$. The basins $(90 \times 90 \times 20 \mathrm{~cm})$ contained 1001 seawater each. Two of these fish basins were installed in the cadmium-contaminated system while the control system only contained one basin. From the fish basins the waste water ran on top of the filter unit. 22 days prior to the start of the experiments the cadmium content of one system was elevated by adding enough $\mathrm{CdCl}_{2}$ to the water to reach a cadmium concentration of about $5 \mu \mathrm{g} / 1$. Each following day $15 \%$ of the water in each system was replaced with new water of the respective kind. Water quality parameters were controlled throughout the experiment ( $\mathrm{S} \%$, $\mathrm{NO}_{2}, \mathrm{PO}_{4}, \mathrm{pH}$ ). Cadmium determination in the control and contaminated system was conducted daily. The experiments were performed at $13.7-15.6^{\circ} \mathrm{C}$ (mean: 15.04 \pm 0.26 ) in seawater with a salinity of about $33 \%$ (mean: $33.6 \pm 0.3$ ). 22 days before the start of the experiments both systems were stocked with plaice in order to build up a bacterial population in the biological filter. At the start of the described experiments both filter systems had successfully developed their purification capacity. 


\section{Plaice (Pleuronectes platessa)}

Juvenile plaice (1.0-2.0 g) were caught in the Elbe estuary and transferred to the laboratory where they were allowed to acclimatize for 4 weeks at $15^{\circ} \mathrm{C}$ and $32 \%$ salinity in a recirculated seawater system. The fishes then were transferred to their experimental basins, in which they were kept for more than 280 days (40 specimens in the control and 80 specimens in the cadmium contaminated system). The fish were fed alternately two daily rations of minced fresh Mytilus edulis meat or a ground fish-shrimp mixture at rates between 8 to $15 \%$ food wet weight of their total body weight. Cadmium content of mussles used for food was $0.3 \mathrm{ng} / \mathrm{mg}$ dry wt, maximum values found were near $1.0 \mathrm{ng} / \mathrm{mg}$ dry wt. The ground fish-shrimp mixture contained between 0.25 and $0.38 \mathrm{ng} \mathrm{Cd} / \mathrm{mg}$ dry wt throughout the experiment. The fish were measured and weighed every 14 days. At regular intervals individuals were sacrificed and samples of tissues were taken for cadmium analysis. Tissues analysed for cadmium content were: backbone, fins, gills, liver, muscle (fillet), otoliths, skin (dorsal and ventral).

\section{Mussel (Mytilus edulis)}

Throughout the experiment 98 (control) and 112 (cadmium) (valve length 6-7 cm) Mytilus edulis (from List harbour, North Sea) were kept on the biological filter. Accumulation of cadmium by mussels was measured by analysing total soft tissue of mussels at regular time intervals.

\section{Biological sludge}

With the activation of the filter system, biological sludge, consisting of bacteria and meiofauna (mainly nematoda, copepoda and ciliates), developed in the gravel filter. Throughout the experiment the sludge was collected after stirring the upper $2 \mathrm{~cm}$ of the filter and was then analysed for cadmium content.

\section{Cadmium determination}

Determination of cadmium was accomplished by means of a flameless atomic absorption spectrophotometer (Perkin Elmer Type 300) equipped with an elecas well as biological sludge were dried at $80^{\circ} \mathrm{C}$ for $24 \mathrm{~h}$. The samples were then trodeless discharge lamp. Water samples were treated with $\left(\mathrm{NH}_{4}\right)_{2} \mathrm{~S}_{2} \mathrm{O}_{8}$ and diluted with double distilled water prior to measurement. Samples of fish and mussel tissues placed in $1.5 \mathrm{ml}$ polypropylene test tubes. For cadmium determination the dried matter was digested in a mixture of $\mathrm{HNO}_{3}$ and $\mathrm{HClO}_{4}(1: 4)$, at $60^{\circ} \mathrm{C}$ for $24 \mathrm{~h}$. Cadmium content was then analysed by means of atomic absorption spectrophotometry. 


\section{RESULTS}

\section{Quality of experimental water}

Figure 1 ( $a$ and $b$ ) gives data on the quality and cadmium concentrations of the experimental water. Cadmium concentrations in the control water varied from 0.3 to $1.8 \mu \mathrm{g} / \mathrm{l}$ with a mean value of $1.04 \pm 0.46 \mu \mathrm{g} / \mathrm{l}$, while in the contaminated system concentrations varied between 2.5 and $7.0 \mu \mathrm{g} / 1$ with a mean of $4.6 \pm$ $1.15 \mu \mathrm{g} / \mathrm{l}$.

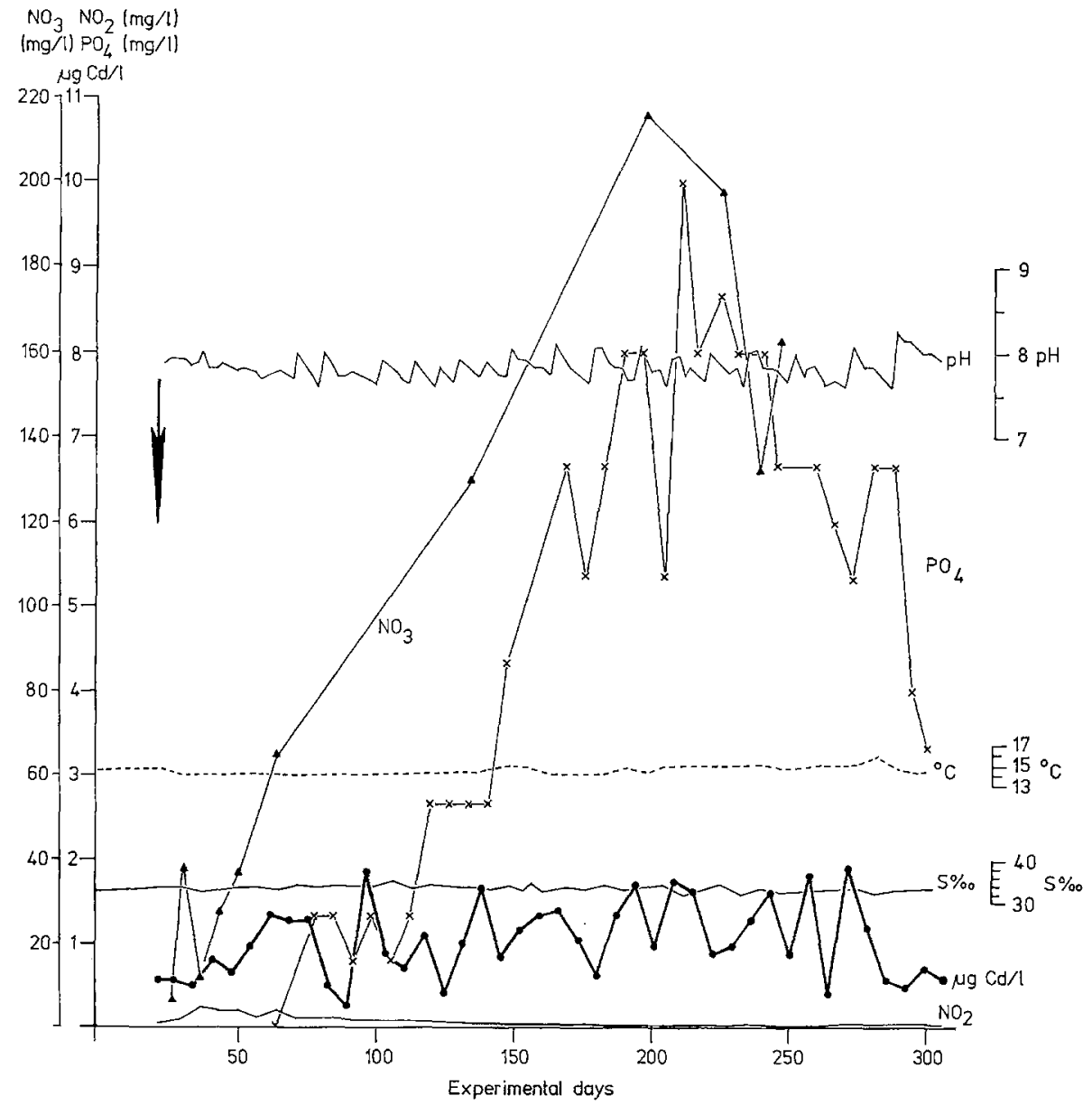

Fig. 1a: Water quality parameters in a recirculated seawater system. Arrows indicate introduction of experimental fish into the system 
Accumulation of cadmium by filter sludge

In Figure 2 cadmium contents of the sludge from the control and the contaminated filter system are depicted. In the control sludge initial cadmium concentration was $1.3 \mathrm{ng} \mathrm{Cd} / \mathrm{mg}$ dry wt. After 300 days maximum values were around $4.0 \mathrm{ng}$ $\mathrm{Cd} / \mathrm{mg}$ dry wt. Cadmium accumulation over the 300 days period was significantly different from zero $\left(0.534>0.393=r_{41} ; 0.001\right)$. Mean cadmium content of the control sludge over the experimental period was $2.01 \pm 0.86 \mathrm{ng} \mathrm{Cd} / \mathrm{mg}$ dry wt. In the sludge of the contaminated system initial values at the beginning of the experiment were around 3.5 to $8.0 \mathrm{ng} \mathrm{Cd} / \mathrm{mg}$ dry wt (y intercept of a linear regression at $7.7 \mathrm{ng} \mathrm{Cd} / \mathrm{mg}$ dry wt). After 300 days cadmium content of the sludge had risen to $17.0 \mathrm{ng} \mathrm{Cd} / \mathrm{mg}$ dry wt. Mean cadmium content over the experimental period was $9.98 \pm 3.5 \mathrm{ng} \mathrm{Cd} / \mathrm{mg}$ dry wt.

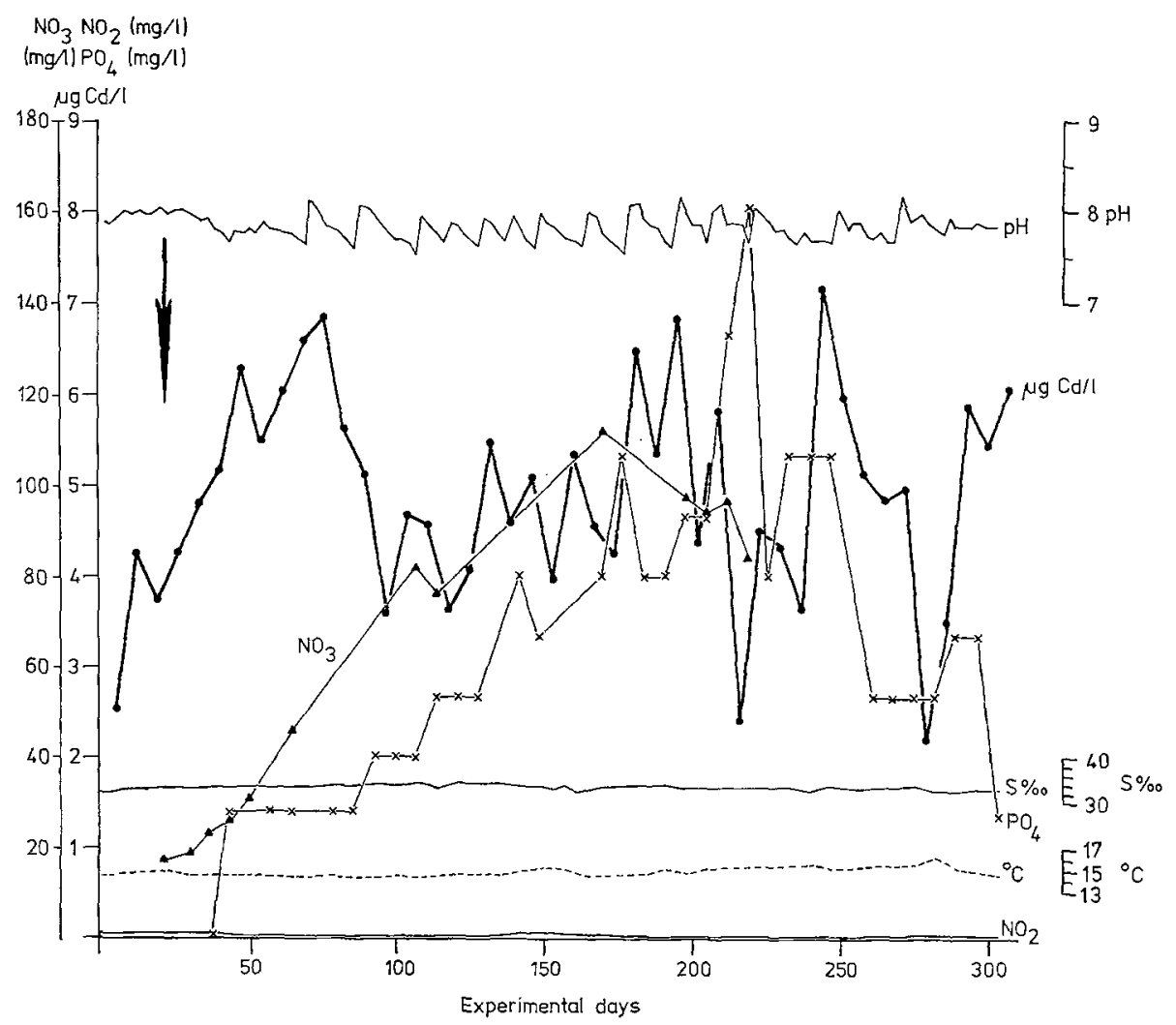

Fig. $1 \mathrm{~b}$ : Water quality parameters in a Cd-contaminated seawater system. Arrows indicate introduction of experimental fish into the system 
Cadmium accumulation over the 300 days period was significantly different from zero $\left(0.381>0.372=r_{45} ; 0.001\right)$. Thus the cadmium content of the sludge of both systems showed a slow, significant increase over the experimental period.

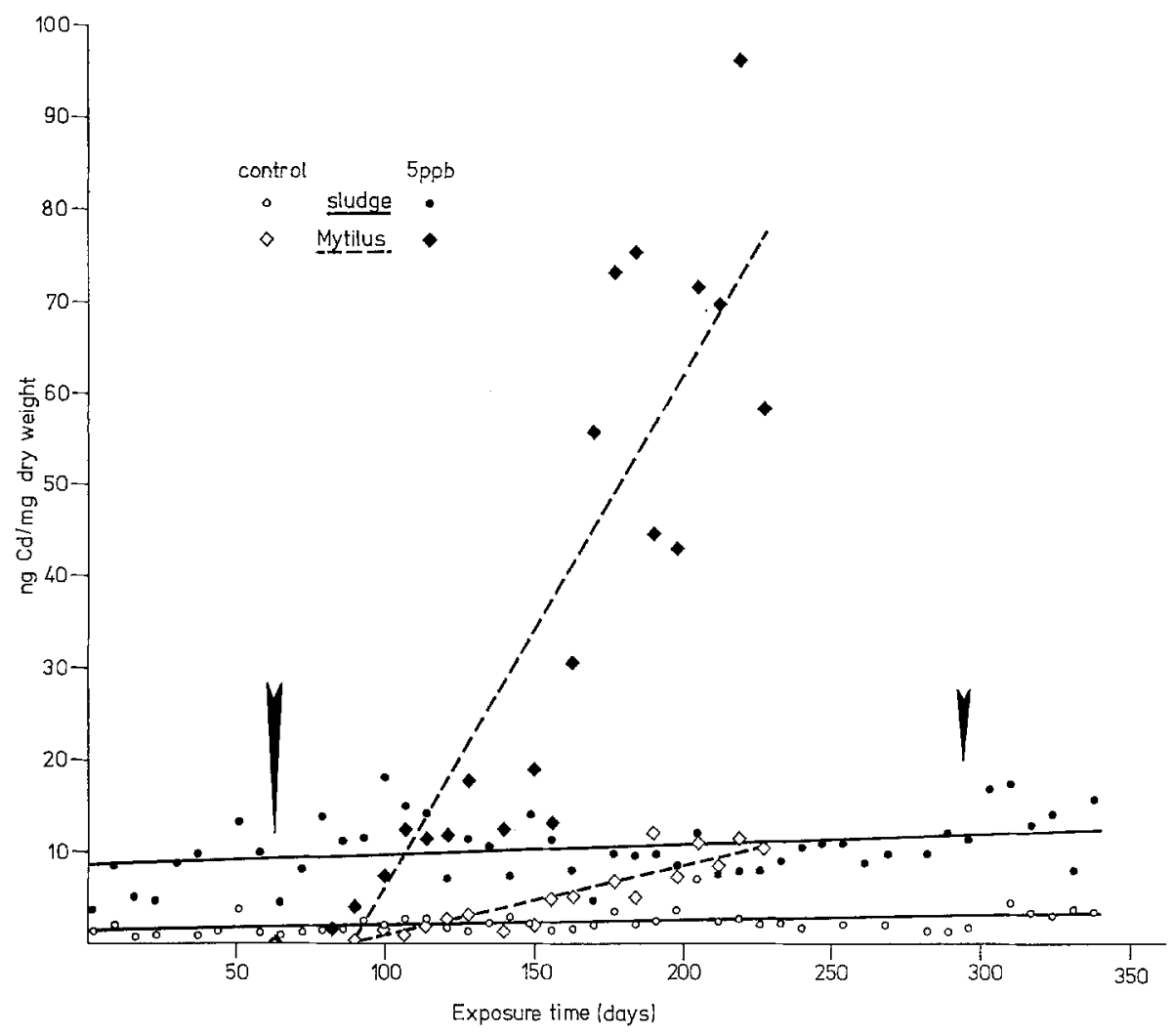

Fig. 2: Accumulation of $\mathrm{Cd}$ by sludge derived from a biological filter and Mytilus edulis in a recirculated seawater system with normal and Cd-contaminated water. For water quality see Figure 1. Large arrow: introduction of Mytilus into the system; small arrow: no further exchange of control and $\mathrm{Cd}$-contaminated water

control sludge: $\mathrm{y}=1.30+0.0046 \times \mathrm{r}_{41}=0.534$; contaminated sludge: $\mathrm{y}=7.76+0.0133 \mathrm{x}$; $\mathrm{r}_{45}=0.381$; control Mytilus: $\mathrm{y}=-1.96+0.0753 \mathrm{x} ; \mathrm{r}_{19}=0.899$; contaminated Mytilus: $\mathrm{y}=-14.5+0.555 \mathrm{x} ; \mathrm{r}_{20}=0.888$

\section{Accumulation of cadmium by musels}

A rapid increase in cadmium content could be observed in soft tissues of Mytilus edulis individuals kept in both systems for 163 days. Whole cadmium body burden of control animals rose from $0.3 \mathrm{ng} \mathrm{Cd} / \mathrm{mg}$ dry wt at the beginning, to around $10 \mathrm{ng} \mathrm{Cd} / \mathrm{mg}$ dry wt after 163 days of exposure (linear regression line $\mathrm{y}=-1.96+$ $0.075 \mathrm{x} ; \mathrm{r}_{19}=0.899$ ). Mussels living in the contaminated system accumulated cadmium up to a whole body burden of $70.7 \mathrm{ng} \mathrm{Cd} / \mathrm{mg}$ dry wt (linear regression: $\mathrm{y}=$ $\left.-14.5+0.56 \times \mathrm{r}_{20}=0.888\right)$. 


\section{Accumulation of cadmium by plaice}

As can be seen in Figure 3, cadmium concentrations in the liver of control specimens increased to a certain extent. Muscle and gill tissues contained very low levels of cadmium, never reaching values higher than $0.2 \mathrm{ng} \mathrm{Cd} / \mathrm{mg}$ dry wt.

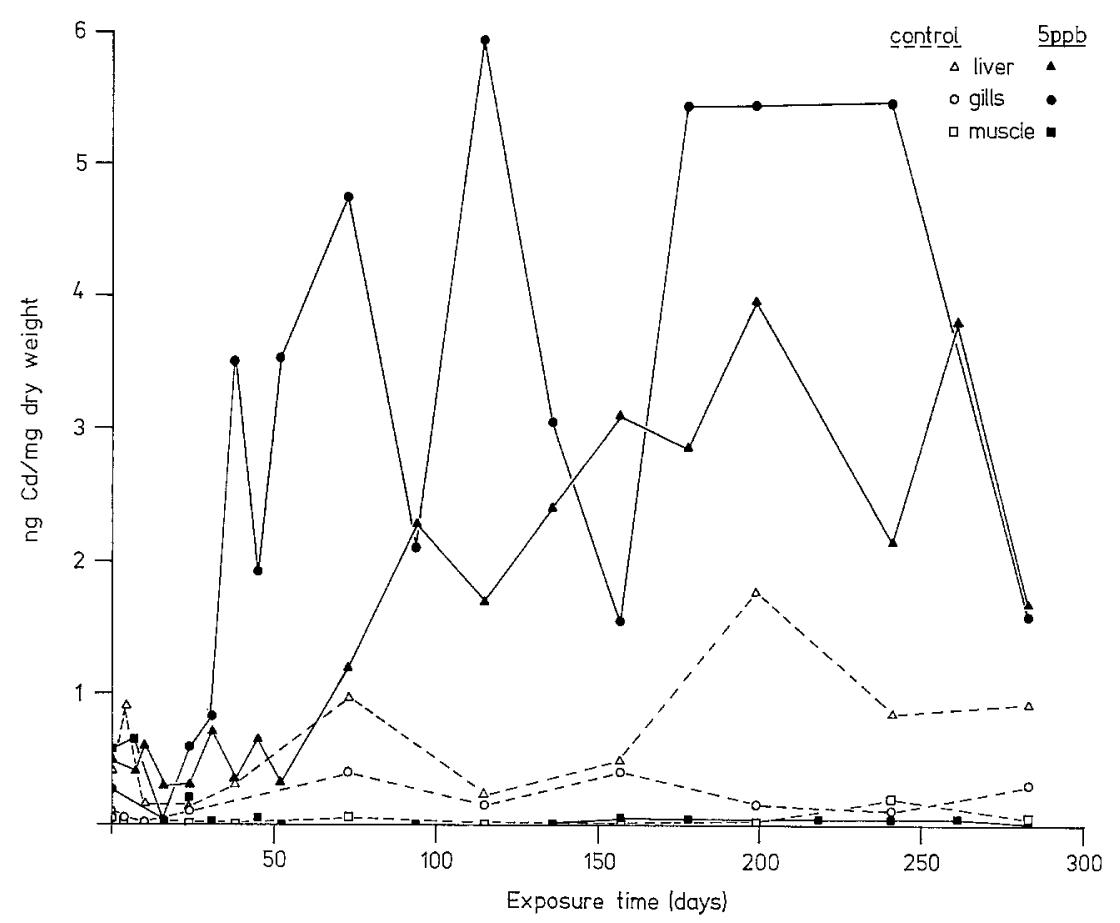

Fig. 3: Cadmium uptake by plaice, Pleuronectes platessa, exposed to $5 \mathrm{ppb}$ cadmium in a recirculated seawater system with partial water exchange. For water quality see Figure 1

In cadmium-exposed fish liver and gills showed significant accumulation of the metal only after 25 to 30 days. After about 40 days cadmium content in gills rose from less than 1.0 to $3.5 \mathrm{ng} \mathrm{Cd} / \mathrm{mg}$ dry wt and to almost $6.0 \mathrm{ng} \mathrm{Cd} / \mathrm{mg}$ dry wt after 115 days. Cadmium concentration in the gills experienced strong fluctuations throughout the course of the experiment. Levels of cadmium in the liver rose after 10 days of exposure to more than $1.0 \mathrm{ng} \mathrm{Cd} / \mathrm{mg}$ dry wt reaching maximum values of $4.0 \mathrm{ng} \mathrm{Cd} / \mathrm{mg}$ dry wt after 200 days. Strong fluctuations in cadmium concentrations of the liver were encountered, but they were not as pronounced as those occurring in the gills. Cadmium concentrations in muscle samples were low throughout the experiment.

Table 1 lists means and range of cadmium values recorded from specimens sacrificed at the start and at the termination of the experiment after 283 days.

Except for liver and backbone differences in cadmium content of control samples from the start and after the experimental period are not significant $(P>$ 
0.05). Cadmium content in liver and gills of metal-exposed plaice was significantly higher than found in control animals. All other tissues tested showed no significant cadmium accumulation over the experimental period, when compared with controls. As can be seen from the indicated range, individual variations in cadmium content of certain tissues are high.

Table 1

Cadmium content in tissues of plaice, Pleuronectes platessa, reared for 283 days in a control $(\mathrm{n}=4)$ and a cadmium contaminated $(5 \mu \mathrm{g} / \mathrm{l}, \mathrm{n}=8)$ recirculated seawater system as $\mathrm{ng}$ $\mathrm{Cd} / \mathrm{mg}$ dry wt

\begin{tabular}{|c|c|c|c|c|c|c|c|c|}
\hline \multirow[t]{2}{*}{ Tissue } & \multicolumn{2}{|c|}{ Control + Cd start (I) } & \multicolumn{2}{|c|}{ Control end (II) } & \multicolumn{2}{|c|}{ Cadmium end (III) } & \multirow[b]{2}{*}{$(\mathrm{I}, \mathrm{II})$} & \\
\hline & $\bar{x}$ & range & $\overline{\mathrm{x}}$ & range & $\bar{x}$ & range & & (II, III) \\
\hline backbone & 0.023 & $0.014-0.049$ & 0.078 & $0.018-0.128$ & 0.206 & $0.041-0.399$ & $<0.05$ & $>0.05$ \\
\hline & 0.017 & $0.005-0.042$ & 0.064 & $0.055-0.079$ & 0.028 & $0.005-0.086$ & & \\
\hline fin (dorsal) & 0.109 & $0.028-0.160$ & 0.205 & $0.068-0.395$ & 0.321 & $0.105-0.587$ & .05 & 0.05 \\
\hline gills & 0.3 & $0.190-0.524$ & 0.290 & $0.190-0.363$ & 1.510 & $0.530-3.401$ & $>0.05$ & $<0.05$ \\
\hline liver & 0.214 & $0.032-0.439$ & 0.917 & $0.460-1.604$ & 1.617 & $0.820-2.800$ & $<0.05$ & $<0.05$ \\
\hline $\begin{array}{l}\text { otoliths } \\
\text { skin }\end{array}$ & 0.195 & $0.005-0.370$ & 0.179 & $0.133 \cdots 0.261$ & 0.482 & $0.177-0.576$ & $>0.05$ & $>0.05$ \\
\hline (dorsal) & 0.082 & $0.039-0.164$ & 0.084 & $0.047-0.123$ & 0.149 & $0.038-0.272$ & $>0.05$ & $>0.05$ \\
\hline (ventral) & 0.100 & $0.027-0.168$ & 0.089 & $0.039-0.138$ & 0.130 & $0.080-0.192$ & $>0.05$ & $>0.05$ \\
\hline
\end{tabular}

\section{Sublethal effects of cadmium on plaice}

Growth of the fish over a period of 265 days is depicted in Figure 4. From the 70th day until the 180th day control fish grew significantly (t-test, $\mathrm{P}<0.05$ ) better than specimens kept in the contaminated system. After 180 days differences were not significant anymore $(\mathrm{P}>0.05)$, probably because the sample size was too low $(\mathrm{n}=10)$. Fish living in the contaminated system were highly excitable when exposed to sudden mechanical-shock waves or sudden optical stimuli. During the measuring and weighing procedures fish from the cadmium system were more difficult to handle than control animals due to increased activity ("nervousness"). After 200 days of experiments this phenomenon subsided and behavioural differences between control and cadmium exposed fish were not detectible anymore. During the experimental period there was no significant difference in mortality rates between control and cadmium exposed fish. The experimental animals showed no apparent ill effects from cadmium.

\section{Effects of cadmium on the biological filter systems}

During the experiments there was no indication of the cadmium hampering the purification capacity of the contaminated filter system (Fig. $1 \mathrm{~b}$ ). $\mathrm{NO}_{2}$ values in the 


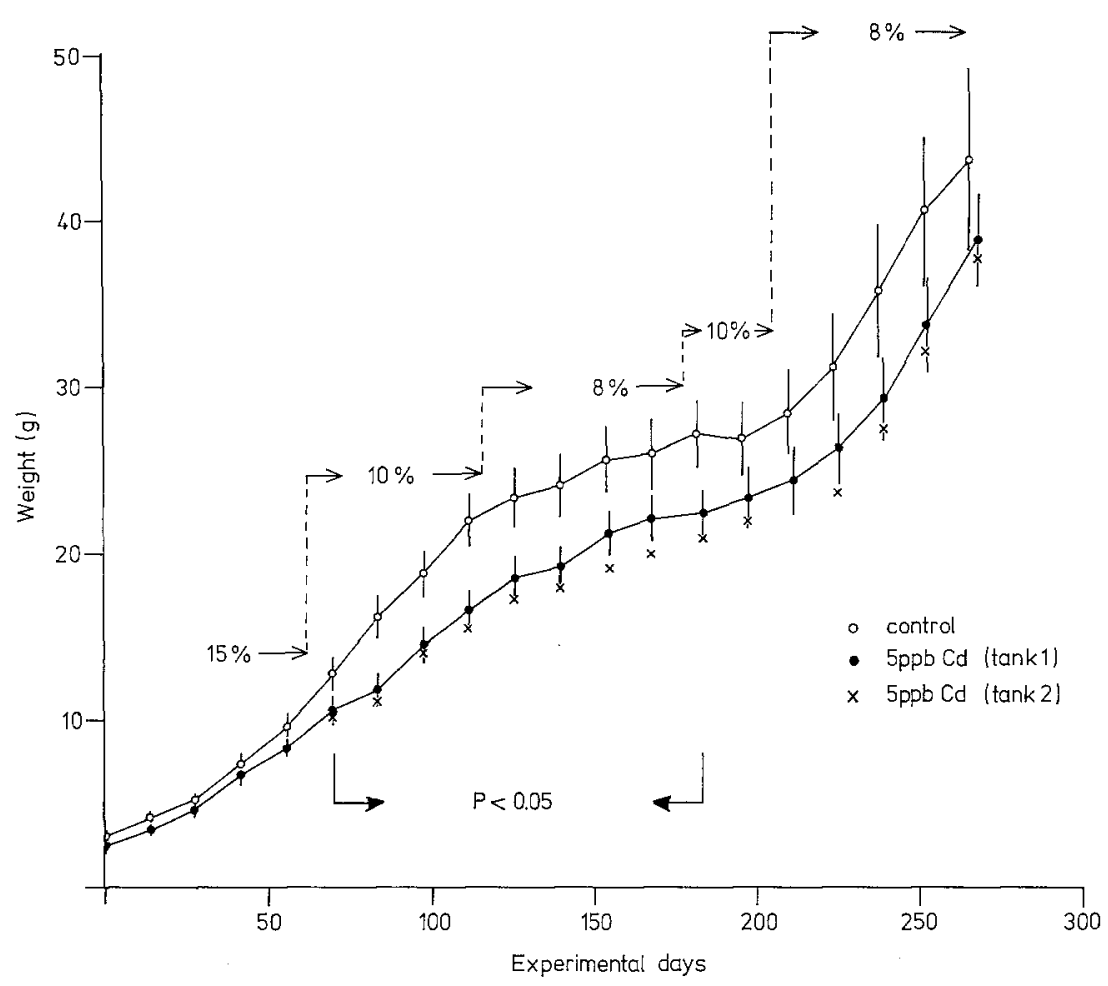

Fig. 4: Growth of plaice, Pleuronectes platessa, in a control and Cd-contaminated recirculated seawater system. Daily rations of food indicated as $\%$ total fish biomass. $P$ : indication of significant growth differences (t-test). For water quality see Figure 1

control water varied from $0.05-0.28$, while the values recorded in the contaminated system never exceeded $0.1 \mathrm{mg} \mathrm{NO} / 1 . \mathrm{NO}_{3}$ values in control water were at maximum after 170 days reaching almost $200 \mathrm{mg} \mathrm{NO} / \mathrm{l}$. In the contaminated system $\mathrm{NO}_{3}$ concentrations never went beyond $115 \mathrm{mg} \mathrm{NO} / \mathrm{l}$. A similar relationship existed with the increase of $\mathrm{PO}_{4}$ in both systems. Maximum phosphate concentration in the controls were $150 \mathrm{mg} / \mathrm{l}$, while in the contaminated system maximum values were $120 \mathrm{mg} / \mathrm{l}$.

\section{DISCUSSION}

\section{Cadmium concentration in water}

Cadmium concentrations in the seawater of the contaminated system were reasonably stable over the experimental time. Even after we discontinued adding cadmium to the system (Fig. 2, day 294), its level in the sludge and the water (Fig. 1 b) did not drop until the experiment was terminated after a further 40 days. This method therefore seems to be suitable for investigating long-term effects of 
heavy metals on organisms in laboratories when large amounts of seawater as required for a flow-through system are not available. The method compensates for the shortcomings of static test methods by offering stable water quality and stable toxicant-concentration for long periods of time. In addition it offers possibilities to investigate the dynamics of toxicants in a model ecosystem.

\section{Filtersystem}

Cadmium accumulation in the sludge of the biological filter was fairly rapid (Fig. 2), reaching a plateau around $10 \mathrm{ppm}(\mathrm{ng} / \mathrm{mg}$ dry wt) 30 days after the first addition of cadmium to the system. This indicated, that after an initial period of accumulation a final saturation point was reached and no further cadmium accumulated in the sludge occurred.

A linear regression line fitted to the data after the 50th day intercepted the $y$-axis at $10.04 \mathrm{ng} \mathrm{Cd} / \mathrm{mg}$ dry wt and ran almost parallel to the $x$-axis $(y=10.04$ $+0.04 \mathrm{x}$ ).

Thus a value of around $10 \mathrm{ng} \mathrm{Cd} / \mathrm{mg}$ dry wt sludge possibly represents a saturation level which is not exceeded even after longer exposure periods, indicating that the accumulation of $\mathrm{Cd}$ by the sludge is mainly due to adsorption on the surfaces of the bacteria, which constitute the bulk of the sludge's biomass (The exact composition of the sludge and the species identification is presently being worked upon and will be the subject of a separate paper). Data gathered from analyses of organic matter and sludge collected from natural water bodies seem to support this view. Cadmium content of organic sediment collected from near shore areas in the North Sea contained 7 ppm cadmium (Dörjes \& Little-Gadow, 1976), sediment of a salt marsh artificially contaminated with this metal contained 12 to $13 \mathrm{ppm}$ cadmium (irrespective of the degree of contamination) (Banus et al., 1975). Experiments conducted by Gardiner (1974) on the adsorptive capacity of fecal matter and other material accumulating in fish tanks yielded an concentration factor of 200 to 1000 after $24 \mathrm{~h}$, a value that agrees well with our findings (Fig. 2). The rapide uptake and the building of a final plateau of cadmium concentration in filter sludge seems to indicate that this uptake is largely due to adsorption processes; after saturation of available surface-binding sites, no further uptake occurs.

During the course of the experiments the purification capacity of the contaminated filtering unit never seemed to be negatively influenced by the heavy metal load. In fact, values for $\mathrm{NO}_{2}$ and $\mathrm{NO}_{3}$ were generally lower in the contaminated system than in the control. Although due to their different sizes the two systems cannot be regarded identical, it is interesting, that the values for $\mathrm{NO}_{2}$ and $\mathrm{NO}_{3}$ were generally lower in the contaminated system than in the control. These findings agree very well with observations of other authors who found no significant growth inhibition of estuarine bacteria up to cadmium concentrations of $0.1 \mathrm{ppm}$, when only the most sensitive strains showed response (Thorman, 1975); and Fargo \& Fleming (1977) did not find any negative effects of cadmium on Nitrosomonas and Nitrobacter bacteria below $100 \mathrm{ppm}$. In fact cadmium up to a concentration of $10 \mu \mathrm{g} / 1 \mathrm{stimul-}$ 
ated estuarine bacteria activity in sewage sludge as observed by Sylvester \& Ware (1977).

$$
\text { Mytilus edulis }
$$

The pattern of accumulation of cadmium by Mytilus edulis in the system as depicted in Figure 2 agrees well with records of heavy metal uptake by filter feeding bivalves. Animals newly introduced into the system contained around $0.3 \mathrm{ppm}$ cadmium (dry weight basis), a value commonly found in total body burden of mussels and other bivalves derived from unpolluted areas (Topping, 1973; Nielsen, 1974; Ratkowski et al., 1974; Nielsen \& Nathan, 1975). Over a relatively short period (25 to 35 days) cadmium values in the experimental animals rose up to 4.0 and $7.0 \mathrm{ppm}$, a value normally found in bivalves collected from polluted areas such as river estuaries and near-shore waters of industrialized areas (Ratkowski et al., 1974; Frazier, 1975; Karbe et al., 1977; Pesch et al., 1977; Bryan \& Aysal, 1978). Eustace, (1974) reports $5.5 \mathrm{ppm} /$ wet weight for Mytilus edulis from the Derwent Estuary (Tasmania) which would correspond to about $25 \mathrm{ppm} / \mathrm{dry}$ wt.

Values of up to $90 \mathrm{ng} / \mathrm{m}$ dry wt $(90 \mathrm{ppm})$ have not yet been found in naturally occurring mussel stocks and are probably only found in artificially contaminated systems. The pattern of cadmium uptake is very similar to that found by SchulzBaldes (1974) for the uptake of lead by Mytilus edulis. The correlation factors for the regression lines (both in control and cadmium system) indicate linear uptake $(\mathrm{P}<0.01)$. The accumulation of considerable amounts of cadmium by specimens held in the control system (Fig. 1 a) might indicate slightly elevated cadmium concentration in the control water. Since the analytical method applied for seawater analysis is a routine technique allowing for analysis of large sample sizes with minimum amounts of seawater, the detection limit was in the range of $0.5 \mu \mathrm{g} \mathrm{Cd} / 1$. Thus nothing can be said as to the real increase of cadmium in the water of the control system. Nevertheless accumulation of cadmium by Mytilus edulis was significant, indicating its sensitivity to increased ambient levels of cadmium.

\section{Pleuronectes platessa}

The levels of cadmium recorded in our experiments for gills and liver varied considerably (Fig. 3). These variations were not due to analytical errors, since most of the data were derived by multiple measuring of the samples. In fact the combined data for the last tissue sample (day 303, Table 1) were remeasured 5 months after the first analysis. Strong variations in the - relatively high - cadmium contents of the gills suggest that the gills are the main site for cadmium uptake from the water and that fluctuations might be related in some way to the transfer of the metal to final storage sites in the body. Differences in the metal contents of liver tissue are well in the range expected for differences between individuals.

While values for cadmium found in fish from the contaminated system are well above metal concentrations detected in fish from natural waters (Won, 1973; Eustace, 
1974; Greig \& Wenzloff, 1977), the values for the control animals agree quite well with data gained from the examination of metal content in wild catches from polluted areas.

Leatherland \& Burton (1974) found $0.03 \mathrm{ppm}$ cadmium in the muscle of plaice from the Solent region, and the data given by Topping (1973) for plaice from Scottish waters are similar. Cadmium content in liver as reported by Portmann (1972) for North Sea plaice are between 0.05 and $0.12 \mathrm{ppm}$ wet wt (to be applied with a factor of 2 for dry wt) and are well within the range of most of our data gained from control specimens. The slight increase in cadmium content of the livers of control fish after 180 days could be due to a new charge of feed mussels, the new mussels having slightly higher total body loads of cadmium than those fed before this period.

Only for heavily polluted areas such as the Severn Estuary (Hardisty et al., 1974) values for cadmium contents in liver of wild catches (21.2 ppm) equal or surpass cadmium content measured in specimens of the described experiments, indicating high metal concentrations in the seawater of those areas. When comparing our data with the results of other authors who conducted similar experiments, we notice that generally bone and muscle accumulate little cadmium (Cearley $\&$ Coleman, 1974).

In experiments conducted with winter flounder (Pseudopleuronectes americanus) exposed for 60 days to 5 and $10 \mu \mathrm{g} / \mathrm{l}$ cadmium (Calabrese et al., 1975) uptake of cadmium was not detectable $(<0.3 \mathrm{ppm})$. Figure 3 shows that in our experiments considerable accumulation occurred only after 70 days, although a slight increase of cadmium-concentrations in the livers was already detected after 10 days of exposure. The results of the experiments with winter flounder are not surprising since total animals were analysed. Experiments conducted with the tautog, Tautogolabrus adspersus, at high concentrations ( $>1$ ppm; Greig et al., 1974) are not directly comparable, since exposure periods were only 4 days. Yet of all tissues examined liver of the experimental fish showed highest cadmium accumulation.

Acknowledgements. We gratefully acknowledge the help of $\mathrm{H}$. Cordes and the crew of F. A. "Neptun" for providing facilities to catch juvenile plaice from the Elbe estuary. We also thank E. Ropers and G. Villa-Riz for skillfull technical assistance.

\section{LITERATURE CITED}

Banus, M. D., Valiela, I. \& Teal, J. M., 1975. Lead, zinc and cadmium budgets in experimentally enriched salt marsh systems. Estuar. coast. mar. Sci. 3, 421-430.

Bryan, G. W. \& Uysal, H., 1978. Heavy metals in the burrowing bivalve Scrobicularia plana from the Tamar estuary in relation to environmental levels. J. mar. biol. Ass. U. K. 58, 89-108.

Butterworth, J., Lester, P. \& Nickles, G., 1972. Distribution of heavy metals in the Severn estuary. Mar. Pollut. Bull. 3, 72-74.

Calabrese, A., Thurberg, F. P., Dawson, M. A. \& Wenzloff, D. R., 1975. Sublethal and physiological stress induced by cadmium and mercury in the winter flounder, Pseudopleuronectes americanus. In: Sublethal effects of toxic chemicals on aquatic animals. Ed. by J. H. Koeman \& I. I. T. W. A. Strik. Elsevier, Amsterdam, 15-21. 
Cearley, J. E. \& Coleman, R. L., 1974. Cadmium toxicity and bioconcentration in largemouth bass and bluegill. Bull. environm. Contam. Toxicol. 11, 146-157.

Chester, R. \& Stoner, J. H., 1974. The distribution of zinc, nickel, manganese, cadmium, copper, and iron in some surface waters from the world ocean. Mar. Chem. 2, 17-32.

Dawson, M. A., Gould, E., Thurberg, F. P. \& Calabrese, A., 1977. Physiological response of juvenile striped bass, Morone saxatilis, to low levels of cadmium and mercury. Cheseapeake Sci. 18, 353-359.

Dörjes, J., Little-Gadow, S. \& Schäfer, A., 1976. Zur Schwermetallverteilung in litoralen Sedimenten der ostfriesischen Küste. Senckenberg. marit. 8, 103-109.

Eisler, R., 1971. Cadmium poisoning in Fundulus beteroclitus (Pisces: Cyprinodontidae) and other marine organisms. J. Fish. Res. Bd Can. 28, 1225-1234.

Eustace, I. J., 1974. Zinc, cadmium, copper and manganese in species of finfish and shellfish caught in the Derwent Estuary, Tasmania. Aust. J. mar. Freshwat. Res. 25, 209-220.

Fargo, L. L. \& Fleming, R. W., 1977. Effects of chromate and cadmium on most probable number estimates of nitrifying bacteria in activated sludge. Bull. environm. Contam. Toxicol. 18, 350-354.

Frazier, J. M., 1975. The dynamics of metals in the American oyster, Crassostrea virginica. I. Seasonal effects. Chesapeake Sci. 16, 161-171.

Gardiner, J., 1974. The chemistry of cadmium in natural water. II. The adsorption of cadmium in river muds and naturally occuring solids. Wat. Res. 8, 157-171.

Greig, R. A., Adams, A. E. \& Nelson, B. A., 1974. Physiological response of the cunner, Tautogolabrus adspersus. II. Uptake of cadmium by organs and tissues. NOAA Tech. Rep. (NMFS, SSRF) 681, 5-9.

- \& Wenzloff, D. R., 1977: Trace metal content of plankton and zooplankton collected from the New York Bight and Long Island Sound. Bull. environm. Toxicol. 18, 3-8.

Hardisty, M. W., Huggins, R. J., Kartar, S. \& Sainsbury, M., 1974. Ecological implications of heavy metal in fish from the Severn estuary. Mar. Pollut. Bull. 5, 12-15.

Karbe, L., Schnier, C. \& Siewers, H. O., 1977. Trace elements in mussels (Mytilus edulis) from coastal areas of the North Sea and the Baltic. Multielement analyses using instrumental neutron activation analysis. J. radioanalyt. Chem. 37, 927-943.

Leatherland, T. M. \& Burton, J. D., 1974: The occurrence of some trace metals in coastal organisms with particular reference to the Solent region. J. mar. biol. Ass. U.K. 54, 457-468.

Macinnes, J. R., Thurberg, F. P., Greig, R. A. \& Gould, E., 1977. Long-term cadmium stress in the cunner, Tawtogolabrus adspersus. Fish. Bull. U.S. 75, 199-203.

NOAA, 1974. Physiological response of the cunner, Tautogolabrus adspersus, to cadmium. NOAA Tech. Rep. (NMFS, SSRF) 681, 1-33.

Nimmo, D. R., Rigby, R. A., Bahner, L. H. \& Sheppard, J. M., 1978. The acute and chronic effects of cadmium on the estuarine mysid, Mysidopsis babia. Bull. environm. Contam. Toxicol. 19, 80-85.

Nielsen, S. A., 1974. Vertical concentration gradients of heavy metals in cultured mussels. N. Z. J. mar. Freshwat. Res. 8, 631-636.

- \& Nathan, A., 1976. Heavy metal levels in New Zealand molluscs. N. Z. J. mar. Freshwat. Res. 9, 467-481.

Pesch, G., Reynolds, B. \& Rogerson, P.; 1977. Trace metals in scallops from within and around two ocean disposal sites. Mar. Pollut. Bull. 8, 224-227.

Portmann, J. E., 1972. The levels of certain metals in fish from coastal waters around England and Wales. Aquaculture 1, 91-96.

Preston, A., 1973. Heavy metals in British waters. Nature, Lond. 242, 95-97.

Ratkowsky, D. A., Thrower, S. J., Eustace, I. J. \& Olley, J., 1974. A numerical study of the concentration of some heavy metals in Tasmanian oysters. J. Fish. Res. Bd Can. 31, 1165-1171.

Schulz-Baldes, M., 1974. Lead uptake from sea water and food, and lead loss in the common mussels Mytilus edulis. Mar. Biol. 25, 177-193.

Sylverster, A. J. \& Ware, G. C., 1977. Laboratory studies on the effect of metals on oxygen uptake by sewage sludge in brackish water. Mar. Pollut. Bull. 8, 45-48. 
Thormann, D., 1975. Uber die Wirkung von Cadmium und Blei auf die natürliche heterotrophe Bakterienflora im Brackwasser des Weser-Ästuars. Veröff. Inst. Meeresforsch. Bremerhaven $15,237-267$.

Topping, G., 1973. Heavy metals in shellfish from Scottish waters. Aquaculture 1, 379-384.

Westernhagen, H. von, Dethlefsen, V. \& Rosenthal, H., 1975. Combined effects of cadmium and salinity on development and survival of garpike eggs. Helgoländer wiss. Meeresunters. 27, 268-282.

Won, J. H., 1973. The concentrations of mercury, cadmium, lead and copper in fish and shellfish of Korea. Bull. Korean Fish. Soc. 6, 1-19. 